\title{
Estimating the Occurrence Probability of Heat Wave Periods Using the Markov Chain Model
}

\author{
Farnood Freidooni ${ }^{1}$, Hooshmand Ataei ${ }^{2} \&$ Fatemeh Shahriar $^{3}$ \\ ${ }^{1}$ Faculty of Engineering, Imam Khomeini International University, Qazvin, Iran \\ ${ }^{2}$ Payamenoor University, Isfahan, Iran \\ ${ }^{3}$ Faculty of Humanities, Najafabad Branch, Islamic Azad University, Najafabad, Isfahan, Iran \\ Correspondence: Fatemeh Shahriar, Faculty of Humanities, Najafabad Branch, Islamic Azad University, \\ Najafabad, Isfahan, Iran. E-mail: af_shahryar@yahoo.com
}

Received: November 21, 2014 Accepted: January 8, 2015 Online Published: March 30, 2015

doi:10.5539/jsd.v8n2p26

URL: http://dx.doi.org/10.5539/jsd.v8n2p26

\begin{abstract}
Regarding the climate changes, global warming, recent drought, forecasting the maximum temperature and hot weather waves has been considered as one of the most important climatic parameters which affects the ecosystems and provides a proper opportunity for the planners to prepare necessary arrangements. Studying and analyzing the maximum temperature is of great importance in managing the water and natural resources, agricultural products, spreading pests and diseases, melting the snow and flood, Evaporation and transpiration, drought and etc. In the present paper, the daily maximum temperature of ten weather stations in northern and southern hillside of Alborz which are geographically corresponded have been collected during 1980 to 2010 in order to determine the hot weather waves in these two hillside and also compare them with each other in April to September, furthermore, a heat index was specified for each month according to the above mentioned data, and the maximum temperatures which were more than the defined index were determined as the heat wave and these waves were categorized into two classes of short term and long term and then the related diagram were drawn and finally using the Markov Chain Model, the transition probability matrix and the reliability probability has been computed with multiple power. The duration period and the return of 1 to ten days for each month and in each weather forecast station was analyzed and studied and then the corresponding stations were compared and the process of temperature changes was discussed. The maximum short term term heat wave in the northern hillside belong terms to Gorgan, the long term heat wave belong terms to Qaem shahr and in the southern hillside, it belong terms to Semnan. The probability of the days, without the heat waves, after which a heat wave occurs, varies between $2 \%$ in Ramsar to $4 \%$ in Gorgan in the station located in the northern hillside; while in the stations located in the southern hillside, this amount varies between 4 to 5\% (except Semnan, 80\%). The results show that the frequency of 1 to 3 days is more than others in all the stations and also in all the seasons and the frequency of 1 to 5 days in the station of southern hillside are more obvious. In the ten days of return, Semnan shows a significant difference compared with other stations.
\end{abstract}

Key words: heat wave, heat index, Markov chain, northern and southern hillside of Alborz

\section{Introduction}

Forecasting the quality and quantity of climatic changes is a subject which has attracted the climatologists' attention. Recognizing the climate system is a basic step in the forecasting process. One of the very important tools which play a significant role in this process is the climatic modeling and basically, understanding the modeling, different models and their various functions is unavoidable in knowing the climate and forecasting the future climate (Asakare, 2007: 210). Temperature, as an index of heat intensity, is one of the significant elements of forecasting the weather. As the earth receives the energy of sun variably, the temperature bears lots of changes which unwontedly results in the wide changes I other elements of weather forecasting (kamali,2002, 1). Therefore, the process of studying the temperature in different temporal- spatial scales has allocated a great part of climatic researches to itself. According to the probability rules, some of the random phenomena (like drought, over rain, flood, heat wave and so on) can be defined through the probability rules (are more probable to occur) (Akan and Houghtalen, 2003, 9). A proper model is chosen in order to compute the occurrence probability of the phenomena; the Markov Chain Model which is employed in the atmospheric sciences in this paper to determine 
the probability of the days with short term and long term heat waves. The Markov Chain model is a mathematic approach for the modeling of random phenomena by which the statistical prediction of frequent occurrence or non-occurrence of phenomena in the future can be done according to the long term-term daily meaningful data collected from the weather forecast stations. Understanding lots of climatic events depends on the comprehension of occurrence probability of these events. The present paper tries to use this approach to study the temperature process in two northern and southern hillside of Alborz by a statistical index named heat wave for the selected weather stations to be properly compared and the frequency prediction of heat waves be determined by the Markov Model. The ecosystems change due to an increase in the heat waves and the intolerable temperature of the weather. The heat waves result in increasing droughts in summer, damaging the agricultural products, firing the forests and also damaging the human bodies' and tourism industry and its related activities. In the early twentieth century the global warming has been frequently started in different parts of the world; this mostly happens in the southern sphere of the globe. Markov Model is frequently used in different sciences. So many researchers and the writers employ this model in their researches.

Grigorten considered the Markov Chain Model useful for the weather forecast from several hours to several weeks (Grigorten, 1966:606). In 1986, Sabra Maniam and sanjiva used the Markov Chain Model to study the products production related with the rain change in the coasts of India. Using the Markov Chain Model, Berger and Goossens (1983:34) analyzed the continuity of wet and dry period in Bulgaria. Colacino et al (Colacino, 1994:183) studied the temperature increase and its result which is heat wave in Mediterranean area and finally divided them into short term and long term waves. Employing the Markov Chain Model in 1998, Wide et al forecasted the wet and dry periods and classified Spain climate according to these periods. Caviar Martin and Lyda Gomez (Martin, 1988:537) categorized the regions in Spain according to the duration of its dry period through using Markov Chain Model. Baron et al used the Markov Chain Model in 2003 in order to study the occurrence of dry periods and its impact on the corn in Africa. In 2003, Anagnostopoulou studied the temporal and spatial changes of dry periods by using the Markov Model. Marina Baldi et al (Baldi, 2004:10) studied the heat wave in Mediterranean area and then analyzed the data collected in 53 summers in Mediterranean area by using the new data; they finally concluded that this event is more evident in July and August, the heat wave is short term in July and it is long term in August. Julio Diaz et al (Diaz, 2006:7) studied the effect of heat wave on the human bodies and examined the reasons of it. Seleshi and Camberlin used this model to study the dry periods in Ethiopia and Mihurta and Sharma studied the daily rain around Sydney and also they proved the capability of this model in estimating the long term term and short term term dry and wet periods. Different researches have been done in Iran which used the Markov Chain Model. In 1968 Hashemi studied the daily statistic of Tehran according to minimum amount of $0.2 \mathrm{~mm}$. In 1983, using the same model, Meshkani examined the probability of wet and dry days repetition in Babolsar. Employing Markov Chain Model, Jafari Behi (1999), examined the wet and dry periods in several weather forecast stations by analyzing the data collected during 30 years. Ashgar Toosi et al (2003:120) used the Markov Model and SPI approach and to study the probability of drought occurrence by SPI approach and showed that three situation of drought, normal and wet can happen according to the zoning maps. Yusefi et al (2007:121) tried to forecast the drought and over rain probability in Qazvin. Asakare et al (2010) studied the probability of dry days in Golestan Province by observing the daily rain of 51 weather forecast station during 20 years and compared the probability of dry days continuity in rainy districts of south and north parts of the province. Farid Hossein et al (2011) used this model to examine the temporal and spatial changes of yearly and seasonal dry periods in Khorasan Province. Alijani et al (Alijani, 2011:4) studied the continuity of two kinds of yearly rain of south of Iran by using the same model. In 2012, Mehdi QamQami and bazr Afshan examined the drought situation of weather forecasting in Iran using the same model in 33 stations during 1976 to 2005 by monthly statistics. In 2011, Yazdan Panah and Alizade started to study the probability of heat wave with different continuity periods in Kerman Province by using Markov Model and found the most amount of heat wave in April and May. The above mentioned findings of the research show that the Chain Markov is an appropriate model in order to predict the frequency of heat waves.

\section{Data and Approach}

The vast mountain range of Alborz which is like a barrier, is located in northern part of Iran and is like a necklace around the neck of Iran has created two different parts in its two hillsides. In the northern hillside, the vegetation is dense, the rainfall is intense, the morphology is specific, while the southern hillside, the dry weather is dominant and the temperature and the rainfall is completely different with the northern hillside. So,

So, in order to reveal these differences and also compare them with each other, the heat waves have been studied by using the Markov Model in corresponding stations in the geographical latitude in two northern and southern hillsides. In the present paper, the daily data of maximum temperature of hot periods of the year from April to 
September of 1980-2010 have been extracted from ten weather forecast stations (regarding the establishment date of the stations).

Table 1 shows the features of these stations and Map 1 shows their situation.

The Markov Chain Model is a model whose structure shows demonstrate the probability of changing from one mode into the other and also it shows the frequency and the occurrence probability. This model is a mathematic approach which is used to model the random phenomena which shows the consecutive monitoring in a period of time. The dependence of this Chain on time is expressed through correlation coefficient or through Transition probability matrix (Alizade et al., 2003). It is supposed in this model that the climate is of two kinds, each outcome depends on t event before it and it doesn't depend on other previous events. In fact, the probability of the occurrence of a climatic phenomenon in the time of $t$ depends greatly on the time of t-1 (Alizade, 2006: 284-285).

Table 1 . The features of the selected weather forecast stations

\begin{tabular}{|c|c|c|c|c|c|c|}
\hline \multirow[t]{2}{*}{ Region } & \multirow[t]{2}{*}{ Station } & \multirow[t]{2}{*}{ long termitude } & \multirow[t]{2}{*}{ latitude } & \multirow[t]{2}{*}{ Height(m) } & \multicolumn{2}{|c|}{$\begin{array}{l}\text { The duration } \\
\text { Statistic period }\end{array}$} \\
\hline & & & & & start & Finish \\
\hline & Astara & $48^{\circ} 51^{\prime}$ & $37^{\circ} \quad 12^{\prime}$ & -21 & 1986 & 2010 \\
\hline The northern & Qaem shahr & $52^{\circ} 46^{\prime}$ & $36^{\circ} \quad 27^{\prime}$ & 14.7 & 1984 & 2010 \\
\hline hillside of & Gorgan & $54^{\circ} 16^{\prime}$ & $36^{\circ} 51^{\prime}$ & 13.3 & 1980 & 2010 \\
\hline \multirow[t]{3}{*}{ Alborz } & Ramsar & $50^{\circ} \quad 40^{\prime}$ & $36^{\circ} 54^{\prime}$ & -20 & 1980 & 2010 \\
\hline & Noshahr & $51^{\circ} \quad 30^{\prime}$ & $36^{\circ} 39^{\prime}$ & -20.9 & 1980 & 2010 \\
\hline & Qazvin & $50^{\circ} \quad 3^{\prime}$ & $36^{\circ} \quad 15^{\prime}$ & 1279.2 & 1980 & 2010 \\
\hline The Southern & Semnan & $53^{\circ} 33^{\prime}$ & $35^{\circ} 35^{\prime}$ & 1130.8 & 1980 & 2010 \\
\hline hillside of & Shahrud & $54^{\circ} \quad 57^{\prime}$ & $36^{\circ} \quad 25^{\prime}$ & 1345.3 & 1980 & 2010 \\
\hline \multirow[t]{2}{*}{ Alborz } & Tehran & $51^{\circ} \quad 19^{\prime}$ & $35^{\circ} \quad 41^{\prime}$ & 1190.8 & 1980 & 2010 \\
\hline & Ardabil & $48^{\circ} \quad 17^{\prime}$ & $38^{\circ}$ & 1332 & 1980 & 2010 \\
\hline
\end{tabular}

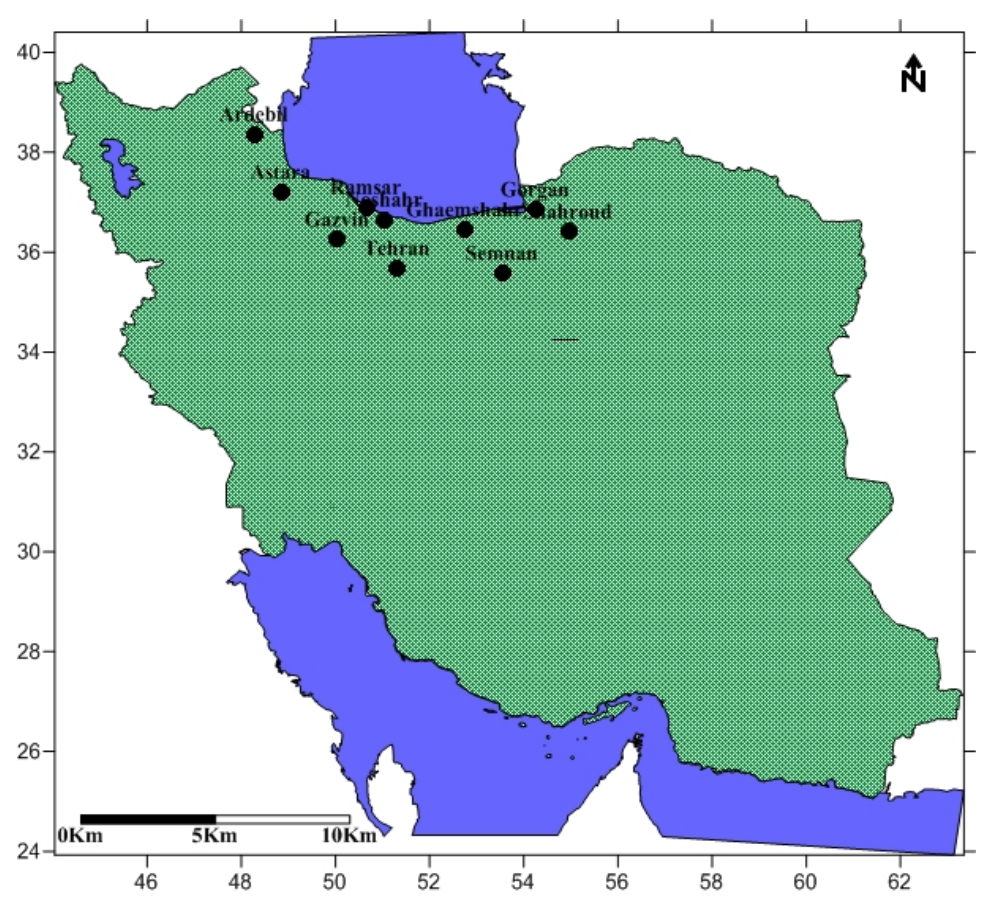

Figure 1. The map of selected regions stations 


\section{Discussion}

\subsection{The Necessary Steps to Implement the Markov Chain Model}

1) First the daily data of maximum temperature of $1980-2010$ is extracted from the selected weather forecast stations.

2) Second, the mean and standard deviation of the data is computed through using the below formula in order to determine the heat wave index.

$$
M=\frac{\sum \mathrm{x}}{\mathrm{n}}
$$

In this formula, $\mathrm{M}$ is the mean of the data, $\mathrm{x}_{\mathrm{I}}$ is the maximum data of the stations and $\mathrm{N}$ is the number of the days.

$$
\delta=\frac{\sqrt{\mathrm{x}_{\mathrm{I}}-m}}{\mathrm{n}}
$$

In this formula, the standard deviation of maximum daily temperature of the stations is computed for all the statistical days.

3) Determination of heat wave index: Baldi Heat Wave Index (2004) is used in order to determine the threshold in which the days are told to have heat waves.

Heat wave $=\mathrm{m}+1 / 5 \times \delta$

The above mentioned formula has been used for all the stations separately and the days in which the maximum temperature is higher than the index were specified.

Table 2. The mean and heat index separated according to month in the southern hillside stations

\begin{tabular}{lcccccccccc}
\hline \multicolumn{10}{c}{ The Southern Hillside of Alborz } \\
\hline & \multicolumn{2}{c}{ Ardabil } & \multicolumn{2}{c}{ Qazvin } & \multicolumn{2}{c}{ Tehran } & \multicolumn{2}{c}{ Semnan } & \multicolumn{2}{c}{ Shahrud } \\
& Mean & $\begin{array}{l}\text { Heat } \\
\text { Index }\end{array}$ & Mean & Heat & Mean & Heat & Mean & Heat & Mean & $\begin{array}{l}\text { Heat } \\
\text { Index }\end{array}$ \\
& & Index & & Index & & Index & Index \\
\hline Apr & 16.5 & 25.6 & 20.4 & 26.9 & 22.7 & 29 & 23.9 & 30.8 & 18.1 & 26.2 \\
May & 20.1 & 27.9 & 25.9 & 32.1 & 28.3 & 34.2 & 29.6 & 35.7 & 23 & 30.4 \\
June & 23.4 & $29 / 8$ & 32.6 & 37.2 & 34.6 & 38.7 & 35.4 & 39.8 & 27.9 & 34.5 \\
July & 25.2 & 31 & 35.4 & 39.2 & 39.8 & 40.4 & 37.5 & 41.6 & 29.9 & 36.1 \\
Aug & 24.6 & 31.4 & 34.5 & 38.3 & 35.5 & 39.1 & 36.2 & 40.3 & 28.8 & 34.6 \\
Sep & 22 & 29.9 & 30.2 & 34.8 & 31.2 & 35.7 & 31.9 & 36.8 & 25 & 31.6 \\
\hline
\end{tabular}

\begin{tabular}{|c|c|c|c|c|c|c|c|c|c|c|}
\hline \multicolumn{11}{|c|}{ The Northern Hillside of Alborz } \\
\hline & \multicolumn{2}{|l|}{ Astara } & \multicolumn{2}{|c|}{ Qaem Shahr } & \multicolumn{2}{|c|}{ Noshahr } & \multicolumn{2}{|c|}{ Gorgan } & \multicolumn{2}{|c|}{ Ramsar } \\
\hline & Mean & Heat & mean & Heat & Mean & Heat & Mean & Heat & Mean & Heat \\
\hline & & Index & & Index & & Index & & Index & & Index \\
\hline Apr & 16.3 & 22.5 & 20 & 27.9 & 16.9 & 22.9 & 21.6 & 30.4 & 16.4 & 22.2 \\
\hline May & 21.8 & 27.1 & 24.6 & 30.9 & 21.8 & 26.7 & 27.1 & 34.7 & 21.4 & 26.2 \\
\hline June & 27.2 & 31.7 & 28.5 & 33 & 26.5 & 30.2 & 31.3 & 37 & 26.3 & 30 \\
\hline July & 30 & 33.7 & 30.6 & 34.4 & 29 & 32 & 33 & 33 & 28.9 & 31.9 \\
\hline Aug & 29.2 & 33.5 & 30.8 & 35.5 & 28.7 & 32.2 & 32.6 & 32.6 & 28.6 & 31.9 \\
\hline Sep & 24.9 & 29.8 & 28 & 32.7 & 25.9 & 29.6 & 29.8 & 29.8 & 25.6 & 29.3 \\
\hline
\end{tabular}

Table 3. The mean and heat index separated according to month in the northern hillside stations 
Then these wave heats were classified into two kinds of short term waves which lasted 3 to 6 days and also long term waves which lasted more than 6 days and the diagram for the short term and long term waves were drawn for each month in all the stations. (Diagram 2-7 and Tables 4-5).

Table 4. The short term and long term waves separated according to month in the northern hillside stations

\begin{tabular}{lccccccccccc}
\hline \multicolumn{10}{c}{ The Northern Hillside of Alborz } \\
\hline & $\begin{array}{l}\text { Astara } \\
\text { short } \\
\text { term }\end{array}$ & $\begin{array}{c}\text { long } \\
\text { term }\end{array}$ & $\begin{array}{l}\text { Qaem shahr } \\
\text { short }\end{array}$ & $\begin{array}{l}\text { long } \\
\text { term }\end{array}$ & $\begin{array}{l}\text { Noshahr } \\
\text { short }\end{array}$ & term & long & $\begin{array}{l}\text { Gorgan } \\
\text { short }\end{array}$ & long & $\begin{array}{l}\text { Ramsar } \\
\text { short }\end{array}$ & long \\
& term & term & term & term & term \\
\hline Apr & - & - & 4 & 4 & 4 & 4 & - & - & 4 & 4 \\
May & - & - & 4.2 & 4 & 4 & 4 & 4.15 & 5 & 4 & 4 \\
June & 8.1 & 4.36 & 4 & 4 & 4.9 & 4.1 & 4.56 & 4 & 4.9 & 4.1 \\
July & 13.16 & 4.5 & 8.3 & 4.2 & 6.26 & 4.03 & 14.23 & 4.5 & 6.5 & 4 \\
Aug & 9.2 & 4.2 & 22 & 6.3 & 8.75 & 4.35 & 4.04 & 4 & 5.5 & 4 \\
Sep & 4 & 4 & 4.6 & 4 & 4 & 4 & 4 & 4 & 4 & 4 \\
\hline
\end{tabular}

Table 5. The short term and long term waves separated according to month in the southern hillside stations

\begin{tabular}{|c|c|c|c|c|c|c|c|c|c|c|}
\hline \multicolumn{11}{|c|}{ The Southern Hillside of Alborz } \\
\hline & \multicolumn{2}{|l|}{ Ardabil } & \multicolumn{2}{|l|}{ Qazvin } & \multicolumn{2}{|c|}{ Tehran } & \multicolumn{2}{|l|}{ Semnan } & \multicolumn{2}{|l|}{ Shahrud } \\
\hline & $\begin{array}{l}\text { Short } \\
\text { term }\end{array}$ & $\begin{array}{l}\text { Long } \\
\text { term }\end{array}$ & $\begin{array}{l}\text { Short } \\
\text { term }\end{array}$ & $\begin{array}{l}\text { Long } \\
\text { term }\end{array}$ & $\begin{array}{l}\text { Short } \\
\text { term }\end{array}$ & $\begin{array}{l}\text { Long } \\
\text { term }\end{array}$ & $\begin{array}{l}\text { Short } \\
\text { term }\end{array}$ & $\begin{array}{l}\text { Long } \\
\text { term }\end{array}$ & $\begin{array}{l}\text { Short } \\
\text { term }\end{array}$ & $\begin{array}{l}\text { Long } \\
\text { term }\end{array}$ \\
\hline Apr & 4.32 & 4 & - & - & - & - & 44.9 & 10.9 & - & - \\
\hline May & 4.21 & 4 & - & - & - & - & 211.8 & 115 & - & - \\
\hline June & 5.91 & 4 & 4.68 & 4 & 6.33 & 4.15 & 42.7 & 40.9 & 30 & 7.6 \\
\hline July & 24.63 & 5.35 & 12.8 & 4.3 & 23.1 & 5.6 & 19.7 & 19.4 & 61 & 18.2 \\
\hline Aug & 21.34 & 4.74 & 6.4 & 4 & 6.6 & 4.1 & 38.6 & 37.2 & 25.7 & 6.2 \\
\hline Sep & 8.23 & 4.04 & - & - & - & - & 158.1 & 109 & 4.1 & 4 \\
\hline
\end{tabular}

4) The frequency of the occurrence of each of the days along term with the heat wave has been computed for the selected stations and a $2 \times 2$ matrix has been formed according to the frequency of the data regarding the events of the days before and after the heat wave and then the frequency of all the data has been computed.

$$
\left[\begin{array}{cc}
\text { noo } & \text { no1 } \\
\text { n10 } & \text { n1 }
\end{array}\right]
$$

5) The computation of the probability matrix of the Markov Model (P) has been written like this for the two modes of the first rank:

$$
\mathrm{P} 01=\frac{n 01}{\mathrm{n} 01 \pm \mathrm{n} 00}, \mathrm{P} 00=1-\mathrm{P} 01
$$

$\mathrm{P} 10=\frac{n 10}{\mathrm{n} 10 \pm \mathrm{n} 11}, \mathrm{P} 11=1-\mathrm{P} 10$

The days which didn't have heat wave were shown as $(0)$ and the days with heat wave were represented as (1) in this matrix. P11 is the probability of existing one day with heat while the day before had wave also and P00 states the probability of the one day without wave before which there was no day with heat wave too (Hejazi Zade and Shirkhani, 2003). The monthly amount of conditional transition probability has been computed for all the selected stations and the results have been shown in table 6-10. 
Table 6. The amount of conditional transition probability separated by month in Astara and Qaem Shahr stations

\begin{tabular}{|c|c|c|c|c|c|c|c|c|}
\hline Region & Station & Month & P00 & P01 & P10 & P11 & $\mathrm{n}(0)$ & $\mathrm{n}(1)$ \\
\hline \multirow{6}{*}{$\begin{array}{l}\text { The Northern } \\
\text { Hillside of } \\
\text { Alborz }\end{array}$} & \multirow{6}{*}{ Astara } & April & $100 \%$ & $0 \%$ & $0 \%$ & $0 \%$ & 767 & 0 \\
\hline & & May & $100 \%$ & $0 \%$ & $0 \%$ & $0 \%$ & 800 & 800 \\
\hline & & June & $99 \%$ & $1 \%$ & $45 \%$ & $55 \%$ & 789 & 11 \\
\hline & & July & $97 \%$ & $3 \%$ & $51 \%$ & $49 \%$ & 734 & 41 \\
\hline & & Aug. & $98 \%$ & $2 \%$ & $58 \%$ & $42 \%$ & 767 & 33 \\
\hline & & Sep. & $100 \%$ & $0 \%$ & $1 \%$ & $0 \%$ & 631 & 1 \\
\hline Region & Station & Month & P00 & P01 & P10 & P11 & $\mathrm{n}(0)$ & $\mathrm{n}(0)$ \\
\hline \multirow{6}{*}{$\begin{array}{l}\text { The Northe } \\
\text { Hillside } \\
\text { Alborz }\end{array}$} & \multirow{6}{*}{$\begin{array}{l}\text { Qaem } \\
\text { Shahr }\end{array}$} & April & $100 \%$ & 05 & $100 \%$ & $0 \%$ & 824 & 4 \\
\hline & & May & $100 \%$ & $0 \%$ & $88 \%$ & $12 \%$ & 856 & 8 \\
\hline & & June & $99 \%$ & $1 \%$ & $75 \%$ & $25 \%$ & 864 & 16 \\
\hline & & July & $98 \%$ & $2 \%$ & $54 \%$ & $46 \%$ & 815 & 22 \\
\hline & & Aug & $97 \%$ & $3 \%$ & $40 \%$ & $60 \%$ & 804 & 60 \\
\hline & & Sep & $99 \%$ & $1 \%$ & $67 \%$ & $33 \%$ & 677 & 6 \\
\hline
\end{tabular}

Table7. The amount of conditional transition probability separated by month in Gorgan and Noshahr stations

\begin{tabular}{|c|c|c|c|c|c|c|c|c|}
\hline Region & Station & Month & $\mathrm{P} 00$ & $\mathrm{P} 01$ & P10 & $\mathrm{P} 11$ & $\mathrm{n}(0)$ & $\mathrm{n}(1)$ \\
\hline \multirow{6}{*}{$\begin{array}{l}\text { The Northern } \\
\text { Hillside of } \\
\text { Alborz }\end{array}$} & \multirow{6}{*}{ Gorgan } & April & $100 \%$ & $0 \%$ & - & - & 951 & 0 \\
\hline & & May & $99 \%$ & $1 \%$ & $88 \%$ & $12 \%$ & 983 & 9 \\
\hline & & June & $97 \%$ & $3 \%$ & $80 \%$ & $20 \%$ & 951 & 41 \\
\hline & & July & $97 \%$ & $3 \%$ & $53 \%$ & $47 \%$ & 912 & 49 \\
\hline & & August & $96 \%$ & $4 \%$ & $64 \%$ & $36 \%$ & 982 & 99 \\
\hline & & Sep. & $99 \%$ & $1 \%$ & $100 \%$ & $0 \%$ & 779 & 5 \\
\hline \multirow[t]{2}{*}{ Region } & Station & Month & $\mathrm{P} 00$ & $\mathrm{P} 01$ & $\mathrm{P} 10$ & P11 & $\mathrm{n}(0)$ & $\mathrm{n}(1)$ \\
\hline & & April & $\% 100$ & $\% 0$ & $\% 100$ & $\% 0$ & 889 & 1 \\
\hline \multicolumn{2}{|l|}{ The Northern } & May & $\% 100$ & $\% 0$ & $\% 100$ & $\% 0$ & 927 & 1 \\
\hline Hillside of & Noshahr & June & $\% 100$ & $\% 0$ & $50 \%$ & $50 \%$ & 926 & 2 \\
\hline \multirow[t]{3}{*}{ Alborz } & & July & $99 \%$ & $1 \%$ & $65 \%$ & $35 \%$ & 882 & 17 \\
\hline & & Aug & $99 \%$ & $1 \%$ & $48 \%$ & $52 \%$ & 905 & 23 \\
\hline & & Sep. & $100 \%$ & $0 \%$ & $100 \%$ & $0 \%$ & 732 & 1 \\
\hline
\end{tabular}


Table 8. The amount of conditional transition probability separated by month in Ramsar and Qazvin stations

\begin{tabular}{|c|c|c|c|c|c|c|c|c|}
\hline Region & Station & Month & P00 & P01 & P10 & P11 & $\mathrm{n}(0)$ & $\mathrm{n}(1)$ \\
\hline \multirow{6}{*}{$\begin{array}{l}\text { The Northern } \\
\text { Hillside of } \\
\text { Alborz }\end{array}$} & \multirow{6}{*}{ Ramsar } & April & $100 \%$ & $0 \%$ & $100 \%$ & $0 \%$ & 949 & 2 \\
\hline & & May & $100 \%$ & $0 \%$ & $100 \%$ & $0 \%$ & 991 & 1 \\
\hline & & June & $100 \%$ & $0 \%$ & $50 \%$ & $50 \%$ & 990 & 2 \\
\hline & & July & $98 \%$ & $2 \%$ & $67 \%$ & $33 \%$ & 940 & 21 \\
\hline & & August & $99 \%$ & $1 \%$ & $71 \%$ & $29 \%$ & 971 & 21 \\
\hline & & Sep. & $100 \%$ & $0 \%$ & $100 \%$ & $0 \%$ & 783 & 1 \\
\hline Region & Station & Month & P00 & P01 & P10 & P11 & $\mathrm{n}(0)$ & $\mathrm{n}(1)$ \\
\hline \multirow{6}{*}{$\begin{array}{l}\text { The Southern } \\
\text { Hillside of } \\
\text { Alborz }\end{array}$} & \multirow{6}{*}{ Qazvin } & April & $100 \%$ & $0 \%$ & - & - & 951 & 0 \\
\hline & & May & $100 \%$ & $0 \%$ & - & - & 992 & 0 \\
\hline & & June & $99 \%$ & $1 \%$ & $71 \%$ & $29 \%$ & 985 & 7 \\
\hline & & July & $97 \%$ & $3 \%$ & $58 \%$ & $42 \%$ & 911 & 50 \\
\hline & & August & $99 \%$ & $1 \%$ & $65 \%$ & $35 \%$ & 969 & 23 \\
\hline & & Sep. & $100 \%$ & $0 \%$ & - & - & 784 & 0 \\
\hline
\end{tabular}

Table 9. The amount of conditional transition probability separated by month in Tehran and Semnan stations

\begin{tabular}{lllllllll}
\hline Region & Station & Month & P00 & P01 & P10 & P11 & $\mathrm{n}(0)$ & $\mathrm{n}(1)$ \\
\hline \multirow{3}{*}{$\begin{array}{l}\text { The Southern } \\
\text { Hillside of }\end{array}$} & & April & $100 \%$ & $0 \%$ & - & - & 951 & 0 \\
Alborz & May & $100 \%$ & $0 \%$ & - & - & 992 & 0 \\
& & June & $99 \%$ & $1 \%$ & $50 \%$ & $50 \%$ & 984 & 8 \\
& & July & $96 \%$ & $4 \%$ & $46 \%$ & $54 \%$ & 890 & 71 \\
& & August & $99 \%$ & $1 \%$ & $60 \%$ & $40 \%$ & 972 & 20 \\
\hline Region & September & $100 \%$ & $0 \%$ & - & - & 784 & 0 \\
\hline & Station & Month & P00 & P01 & P10 & P11 & $\mathrm{n}(0)$ & $\mathrm{n}(1)$ \\
& & April & $95 \%$ & $5 \%$ & $36 \%$ & $64 \%$ & 814 & 137 \\
& & May & $76 \%$ & $24 \%$ & $14 \%$ & $86 \%$ & 430 & 562 \\
& & June & $42 \%$ & $58 \%$ & $1 \%$ & $99 \%$ & 24 & 968 \\
& & July & $20 \%$ & $80 \%$ & $0 \%$ & $100 \%$ & 50 & 956 \\
& & August & $46 \%$ & $54 \%$ & $0 \%$ & $100 \%$ & 13 & 979 \\
& September & $72 \%$ & $0 \%$ & $91 \%$ & $9 \%$ & 151 & 632 \\
\hline
\end{tabular}


Table10. The amount of conditional transition probability separated by month in Shahrud and Ardabil stations

\begin{tabular}{|c|c|c|c|c|c|c|c|c|}
\hline Region & Station & Month & P00 & P01 & P10 & P11 & $\mathrm{n}(0)$ & $\mathrm{n}(1)$ \\
\hline \multirow{6}{*}{$\begin{array}{l}\text { The southern } \\
\text { Hillside of } \\
\text { Alborz }\end{array}$} & \multirow{6}{*}{ Shahrud } & April & $100 \%$ & $0 \%$ & - & - & 921 & 0 \\
\hline & & May & $100 \%$ & $0 \%$ & - & - & 960 & 0 \\
\hline & & June & $96 \%$ & $4 \%$ & $39 \%$ & $61 \%$ & 893 & 67 \\
\hline & & July & $94 \%$ & $6 \%$ & $29 \%$ & $71 \%$ & 780 & 150 \\
\hline & & August & $96 \%$ & $4 \%$ & $43 \%$ & $57 \%$ & 872 & 88 \\
\hline & & Sep. & $99 \%$ & $1 \%$ & $91 \%$ & $9 \%$ & 747 & 11 \\
\hline Region & Station & Month & P00 & P01 & $\mathrm{P} 10$ & P11 & $\mathrm{n}(0)$ & $\mathrm{n}(1)$ \\
\hline \multirow{6}{*}{$\begin{array}{l}\text { The southern } \\
\text { Hillside of } \\
\text { Alborz }\end{array}$} & \multirow{6}{*}{ Ardabil } & April & $78 \%$ & $22 \%$ & $66 \%$ & $34 \%$ & 948 & 3 \\
\hline & & May & $99 \%$ & $1 \%$ & $86 \%$ & $14 \%$ & 985 & 7 \\
\hline & & June & $96.3 \%$ & $3.7 \%$ & $79 \%$ & $21 \%$ & 944 & 48 \\
\hline & & July & $95 \%$ & $5 \%$ & $49 \%$ & $51 \%$ & 880 & 81 \\
\hline & & August & $95 \%$ & $5 \%$ & $54 \%$ & $46 \%$ & 904 & 88 \\
\hline & & Sep. & $96 \%$ & $4 \%$ & $69 \%$ & $31 \%$ & 736 & 48 \\
\hline
\end{tabular}

Two basic questions which are asked about the above mentioned matrix is that whether the frequency is the independent mode or they follow the two-mode Markov Chain Model.

The second question is that based on the hypothesis of zero are the data without any specific process or based on the contrary hypothesis, they follow a specific process. In order to evaluate this matrix, the frequency is computed in two steps by the two-mode Markov Chain Model.

A. Persistence: the below formula is used in order to prove the persistence. If the achieved result is larger than zero, it is persistent and if the result is smaller than zero, it shows the lack of persistence (Alijani, 2011).

$$
\mathbf{r}=\mathbf{P 1 1}-\mathbf{P 0 1}
$$

The significance of persistence is achieved through $\mathrm{X} 2$ in which it is supposed that there is no lack of persistence.

$$
\mathrm{X}^{2}=\sum \frac{\left(f_{o-f_{e}}\right) 2}{f_{e}}
$$

$f_{o}$ is the observation value and $f_{e}$ stands for the expected value.

The next step of the Kido test is computing the maximum temperature according to the collected data; and because the statistics were bigger than the extracted Critical Numbers (Asakare, 2011:535); the hypothesis of the stability of the data has been approved by expected Alfa of $99 \%$.

B: Stagnation: this means that the transition probability of all the time periods should be the same. If the statistical period isn't stagnated, they must be changed into stagnated periods. All the powers of probability matrix $(\mathrm{Pk})$ are random matrix. In the transition matrix, when the $\mathrm{K}$ enlarges, a very amazing phenomenon happens, i.e. all the rows of transition matrix would become equal in a way that if the matrix is powered again, there will be no changes in the elements. It means after a specific value on, as we increase $k$, there will be no changes in the probability matrix and the values of the corresponding rows will be equal in the matrix. It is said in this case that the matrix is stagnated. This occurrence probability matrix is called the stagnated matrix. Since the rows are equal in the matrix, it can be shown by a vector and is represented like $\pi j$ (Asakare, 2008:49).

The probability vector of stagnated mode shows how much is the occurrence probability of a rainy day and dry day after a long term period of time (Jalali, 2011: 243).

The transition matrix which has $\mathrm{k}$ steps has been computed to four decimal digits for the heat waves of the selected stations by Matlab software and it has been reached to stagnated mode. The results have been shown in table 11. In fact the row vector of this matrix demonstrates that the long term period of heat wave is possible to happen. 
Table 11. The stagnation probability of the days with or without rain in different seasons in the selected weather forecast station

\begin{tabular}{|c|c|c|c|c|c|}
\hline \multicolumn{3}{|c|}{ Station } & $\begin{array}{c}\text { Stagnation } \\
\text { Rank } \\
\end{array}$ & $\begin{array}{c}\text { The probability of lack of } \\
\text { heat wave }\end{array}$ & $\begin{array}{l}\text { The probability of heat } \\
\text { wave }\end{array}$ \\
\hline \multirow{5}{*}{$\begin{array}{l}\text { The } \\
\text { Hillside }\end{array}$} & \multirow{5}{*}{ Northern } & Gorgan & 9 & 0.9764 & 0.0236 \\
\hline & & Ramsar & 8 & 0.9916 & 0.0084 \\
\hline & & Qaem Shahr & 13 & 0.9787 & 0.0213 \\
\hline & & Noshahr & 12 & 0.9916 & 0.0084 \\
\hline & & Astara & 13 & 0.9813 & 0.0187 \\
\hline \multirow{5}{*}{$\begin{array}{l}\text { The } \\
\text { Hillside }\end{array}$} & \multirow{5}{*}{ Southern } & Qazvin & 10 & 0.9858 & 0.0142 \\
\hline & & Semnan & 43 & 0.2527 & 0.7473 \\
\hline & & Shahrud & 25 & 0.9425 & 0.0575 \\
\hline & & Tehran & 14 & 0.9825 & 0.0175 \\
\hline & & Ardabil & 11 & 0.9516 & 0.0484 \\
\hline
\end{tabular}

6) Predicting the n-day Heat Wave: One of the features of Markov Chain Model is it can be used for the forecasting of $\mathrm{n}$ heat waves which can be achieved through the below formula:

$$
\mathrm{H}_{\mathrm{n}}=1+\frac{(N-n)\left(P_{10}\right)\left(P_{o 1}\right)\left(1-P_{10}\right)}{\left(P_{10}+P_{o 1}\right)}
$$

$\mathrm{H}_{\mathrm{n}}$ is the length of heat wave period, $\mathrm{N}$ stands for the number of all the days of the statistical periods, $\mathrm{n}$ is the length of heat wave (one day, 2 days, 3 days...). The tables below show the frequency of heat wave in each station through the above mentioned formula (Tables 12-21).

Table 12, 13. The frequency of heat wave of $\mathrm{n}$ days in Ardabil station \& Astara station

\begin{tabular}{ccccccc}
\hline n days & \multicolumn{6}{c}{ Astara } \\
\cline { 2 - 7 } & \multicolumn{6}{c}{ Month } \\
\hline & Sep & Aug & July & June & May & April \\
\hline 1 & 2 & 18 & 22 & 8 & - & - \\
2 & 1 & 8 & 11 & 5 & - & - \\
3 & 1 & 4 & 6 & 3 & - & - \\
4 & 1 & 2 & 3 & 2 & - & - \\
5 & 1 & 2 & 2 & 2 & - & - \\
6 & 1 & 1 & 2 & 1 & - & - \\
7 & 1 & 1 & 1 & 1 & - & - \\
8 & 1 & 1 & 1 & 1 & - & - \\
9 & 1 & 1 & 11 & 1 & - & - \\
10 & 1 & 1 & 1 & 1 & - & - \\
\hline
\end{tabular}

\begin{tabular}{ccccccc}
\hline n days & \multicolumn{5}{c}{ Ardabil } \\
\cline { 2 - 6 } & \multicolumn{6}{c}{ Month } \\
\hline & Sep & Aug & July & June & May & April \\
\hline 1 & 31 & 50 & 44 & 36 & 10 & 3 \\
2 & 10 & 23 & 23 & 8 & 2 & 2 \\
3 & 4 & 11 & 12 & 3 & 1 & 1 \\
4 & 2 & 6 & 7 & 1 & 1 & 1 \\
5 & 1 & 3 & 4 & 1 & 1 & 1 \\
6 & 1 & 21 & 2 & 1 & 1 & 1 \\
7 & 1 & 1 & 2 & 1 & 1 & 1 \\
8 & 1 & 1 & 1 & 1 & 1 & 1 \\
9 & 1 & 1 & 1 & 1 & 1 & 1 \\
10 & 1 & 1 & 1 & 1 & 1 & 1 \\
\hline
\end{tabular}


Table 14, 15. The frequency of heat wave of $\mathrm{n}$ days in Qaem Shahr station \& Noshahr station

\begin{tabular}{lllllll}
\hline \multirow{2}{*}{ n Days } & \multicolumn{5}{c}{ Noshahr } \\
\cline { 2 - 7 } & \multicolumn{5}{c}{ Month } \\
\hline 1 & 2 & 10 & 13 & 3 & 2 & 2 \\
2 & 1 & 6 & 5 & 2 & 1 & 1 \\
3 & 1 & 3 & 2 & 2 & 1 & 1 \\
4 & 1 & 2 & 2 & 1 & 1 & 1 \\
5 & 1 & 2 & 1 & 1 & 1 & 1 \\
6 & 1 & 1 & 1 & 1 & 1 & 1 \\
7 & 1 & 1 & 1 & 1 & 1 & 1 \\
8 & 1 & 1 & 1 & 1 & 1 & 1 \\
9 & 1 & 1 & 1 & 1 & 1 & 1 \\
10 & 1 & 1 & 1 & 1 & 1 & 1 \\
\hline
\end{tabular}

\begin{tabular}{cllllll}
\hline \multirow{2}{*}{ n Days } & \multicolumn{5}{c}{ Qaem Shahr } \\
\cline { 2 - 7 } & \multicolumn{6}{c}{ Month } \\
\hline 1 & 5 & 24 & 13 & 1 & 8 & 5 \\
2 & 2 & 15 & 6 & 1 & 2 & 1 \\
3 & 1 & 9 & 3 & 1 & 1 & 1 \\
4 & 1 & 6 & 2 & 1 & 1 & 1 \\
5 & 1 & 4 & 1 & 1 & 1 & 1 \\
6 & 1 & 3 & 1 & 1 & 1 & 1 \\
7 & 1 & 2 & 1 & 1 & 1 & 1 \\
8 & 1 & 2 & 1 & 1 & 1 & 1 \\
9 & 1 & 1 & 1 & 1 & 1 & 1 \\
10 & 1 & 1 & 1 & 1 & 1 & 1 \\
\hline
\end{tabular}

Table 16, 17. The frequency of heat wave of $\mathrm{n}$ days in Gorgan station \& Qazvin station

\begin{tabular}{ccccccc}
\hline \multirow{2}{*}{ n Days } & \multicolumn{7}{c}{ Qazvin } \\
\cline { 2 - 7 } & \multicolumn{7}{c}{ Month } \\
\hline & SEp & August & July & June & May & April \\
\hline 1 & - & 14 & 31 & 7 & - & - \\
2 & - & 6 & 14 & 3 & - & - \\
3 & - & 3 & 6 & 2 & - & - \\
4 & - & 2 & 3 & 1 & - & - \\
5 & - & 1 & 2 & 1 & - & - \\
6 & - & 1 & 1 & 1 & - & - \\
7 & - & 1 & 1 & 1 & - & - \\
8 & - & 1 & 1 & 1 & - & - \\
9 & - & 1 & 1 & 1 & - & - \\
10 & - & 1 & 1 & 1 & - & - \\
\hline
\end{tabular}

\begin{tabular}{ccccccc}
\hline \multirow{2}{*}{ n Days } & \multicolumn{6}{c}{ Gorgan } \\
\cline { 2 - 7 } & \multicolumn{7}{c}{ Month } \\
\hline 1 & 6 & 1 & 27 & 32 & 12 & - \\
2 & 1 & 1 & 13 & 7 & 2 & - \\
3 & 1 & 1 & 7 & 2 & 1 & - \\
4 & 1 & 1 & 4 & 1 & 1 & - \\
5 & 1 & 1 & 2 & 1 & 1 & - \\
6 & 1 & 1 & 2 & 1 & 1 & - \\
7 & 1 & 1 & 1 & 1 & 1 & - \\
8 & 1 & 1 & 1 & 1 & 1 & - \\
9 & 1 & 1 & 1 & 1 & 1 & - \\
10 & 1 & 1 & 1 & 1 & 1 & - \\
\hline
\end{tabular}


Table 18, 19. The frequency of heat wave of $\mathrm{n}$ days in Semnan station \& Shahrud station

\begin{tabular}{ccccccc}
\hline \multirow{2}{*}{ n Days } & \multicolumn{6}{c}{ Shahrud } \\
\cline { 2 - 7 } & \multicolumn{7}{c}{ Month } \\
\hline 1 & 10 & 33 & 46 & 32 & - & - \\
2 & 2 & 19 & 33 & 20 & - & - \\
3 & 1 & 11 & 23 & 13 & - & - \\
4 & 1 & 7 & 17 & 8 & - & - \\
5 & 1 & 4 & 12 & 5 & - & - \\
6 & 1 & 3 & 9 & 4 & - & - \\
7 & 1 & 2 & 7 & 3 & - & - \\
8 & 1 & 2 & 5 & 2 & - & - \\
9 & 1 & 1 & 4 & 2 & - & - \\
10 & 1 & 1 & 3 & 1 & - & - \\
\hline
\end{tabular}

\begin{tabular}{ccccccc}
\hline \multirow{2}{*}{ n Days } & \multicolumn{5}{c}{ Semnan } \\
\cline { 2 - 6 } & Sep & Aug & July & June & May & April \\
\hline 1 & 55 & 10 & 5 & 11 & 90 & 44 \\
2 & 50 & 10 & 5 & 11 & 77 & 28 \\
3 & 45 & 10 & 5 & 11 & 66 & 19 \\
4 & 41 & 10 & 5 & 11 & 56 & 12 \\
5 & 38 & 10 & 5 & 11 & 48 & 8 \\
6 & 34 & 10 & 5 & 11 & 41 & 6 \\
7 & 31 & 9 & 5 & 10 & 36 & 4 \\
8 & 28 & 9 & 5 & 10 & 31 & 3 \\
9 & 26 & 9 & 5 & 10 & 26 & 2 \\
10 & 24 & 9 & 5 & 10 & 23 & 2 \\
\hline
\end{tabular}

Table 20, 21. The frequency of heat wave of $\mathrm{n}$ days in Tehran station \& Ramsar Station

\begin{tabular}{lllllll}
\hline \multirow{2}{*}{ n days } & \multicolumn{5}{c}{ Ramsar } \\
\cline { 2 - 7 } & \multicolumn{5}{c}{ Month } \\
\hline 1 & 2 & 14 & 16 & 3 & 2 & 3 \\
2 & 1 & 5 & 6 & 2 & 1 & 1 \\
3 & 1 & 2 & 3 & 1 & 1 & 1 \\
4 & 1 & 1 & 2 & 1 & 1 & 1 \\
5 & 1 & 1 & 1 & 1 & 1 & 1 \\
6 & 1 & 1 & 1 & 1 & 1 & 1 \\
7 & 1 & 1 & 1 & 1 & 1 & 1 \\
8 & 1 & 1 & 1 & 1 & 1 & 1 \\
9 & 1 & 1 & 1 & 1 & 1 & 1 \\
10 & 1 & 1 & 1 & 1 & 1 & 1 \\
\hline
\end{tabular}

\begin{tabular}{cllllll}
\hline \multirow{2}{*}{ n days } & \multicolumn{6}{c}{ Tehran } \\
\cline { 2 - 7 } & \multicolumn{7}{c}{ Mep } & Aug & July & June & May & April \\
\hline & - & 11 & 35 & 6 & - & - \\
2 & - & 5 & 19 & 3 & - & - \\
3 & - & 3 & 11 & 2 & - & - \\
4 & - & 2 & 6 & 2 & - & - \\
5 & - & 1 & 4 & 1 & - & - \\
6 & - & 1 & 2 & 1 & - & - \\
7 & - & 1 & 2 & 1 & - & - \\
8 & - & 1 & 1 & 1 & - & - \\
9 & - & 1 & 1 & 1 & - & - \\
10 & - & 1 & 1 & 1 & - & - \\
\hline
\end{tabular}

7) The Return Period of Heat Waves of n Days: the return period, is the normal situation of returning a phenomenon which is the opposite the probability situation. Regarding the return period, the normal time period taken for a one day heat wave to be repeated, can be determined. The return period of n-day heat waves can be specified by the below formula (Mahdavi, 2007).

$$
\mathrm{RH}=\frac{p 01+p 10}{(p 01)(p 10)(1-p 10) n}
$$

$\mathrm{Rh}$ is the return period of $\mathrm{n}$-day heat wave. The determination of the return period is applicable in finding the strategies and confronting the probable outcomes. The return period of 1 to 10 days of each station has been drawn in diagrams 22 to 30 .

8) The diagrams related to the heat wave and heat index have been drawn up. 
Table 22. The return period of the occurrence of n-days heat waves in Ardabil station

\begin{tabular}{ccccccc}
\hline \multirow{2}{*}{ N days } & \multicolumn{5}{c}{ Ardabil } \\
\cline { 2 - 7 } & Sep & August & July & June & May & April \\
\hline 1 & 83.16121 & 45.46667 & 44.43169 & 135.526 & 774.2778 & 1426.5 \\
2 & 266.1159 & 100.0267 & 87.77969 & 650.5249 & 5419.944 & 4279.5 \\
3 & 851.5708 & 220.0587 & 173.4184 & 3122.519 & 37939.61 & 12838.5 \\
4 & 2725.027 & 484.1291 & 342.6071 & 14988.09 & 265577.3 & 38515.5 \\
5 & 8720.085 & 1065.084 & 676.8579 & 71942.85 & 1859041 & 115546.5 \\
6 & 27904.27 & 2343.185 & 1337.207 & 345325.7 & 13013287 & 346639.5 \\
7 & 89293.67 & 5155.006 & 2641.799 & 1657563 & 91093006 & 1039919 \\
8 & 285739.7 & 11341.01 & 5219.165 & 7956303 & $6.38 \mathrm{E}+08$ & 3119756 \\
9 & 914367.2 & 24950.23 & 10311.03 & 38190256 & $4.46 \mathrm{E}+09$ & 9359266 \\
10 & 2925975 & 54890.51 & 20370.58 & $1.83 \mathrm{E}+08$ & $3.12 \mathrm{E}+10$ & 28077800 \\
\hline
\end{tabular}

Table 22. The return period of the occurrence of n-days heat waves in Astara station

\begin{tabular}{|c|c|c|c|c|c|c|}
\hline \multirow[t]{3}{*}{ n days } & \multicolumn{6}{|c|}{ Astara } \\
\hline & \multicolumn{6}{|c|}{ Month } \\
\hline & Sep & August & July & June & May & April \\
\hline 1 & 6320001 & 110.4427 & 75.65476 & 210.6762 & - & - \\
\hline 2 & $6.32 \mathrm{E}+10$ & 260.3293 & 155.0923 & 386.2397 & - & - \\
\hline 3 & $6.32 \mathrm{E}+14$ & 613.6333 & 317.9391 & 708.1061 & - & - \\
\hline 4 & $6.32 \mathrm{E}+18$ & 1446.421 & 651.7752 & 1298.194 & - & - \\
\hline 5 & $6.32 \mathrm{E}+22$ & 3409.422 & 1336.139 & 2380.023 & - & - \\
\hline 6 & $6.32 \mathrm{E}+26$ & 8036.494 & 2739.085 & 4363.376 & - & - \\
\hline 7 & $6.32 \mathrm{E}+30$ & 18943.16 & 5615.125 & 7999.523 & - & - \\
\hline 8 & $6.32 \mathrm{E}+34$ & 44651.75 & 11511.01 & 14665.79 & - & - \\
\hline 9 & $6.32 \mathrm{E}+38$ & 105250.5 & 23597.56 & 26887.28 & - & - \\
\hline 10 & $6.32 \mathrm{E}+42$ & 248090.6 & 48375 & 49293.35 & - & - \\
\hline
\end{tabular}


Table 23. The return period of the occurrence of n-days heat waves in Qaem Shahr station

\begin{tabular}{|c|c|c|c|c|c|c|}
\hline \multirow[t]{3}{*}{ n Days } & \multicolumn{6}{|c|}{ Qaem Shahr } \\
\hline & \multicolumn{6}{|c|}{ Month } \\
\hline & Sep & Aug & July & June & May & April \\
\hline 1 & 512.25 & 62.42754 & 153.45 & 350.9333 & 987.4286 & 2070001 \\
\hline 2 & 1536.75 & 104.0459 & 337.59 & 1403.733 & 7899.429 & $2.07 \mathrm{E}+10$ \\
\hline 3 & 4610.25 & 173.4098 & 742.698 & 5614.933 & 63195.43 & $2.07 \mathrm{E}+14$ \\
\hline 4 & 13830.75 & 289.0164 & 1633.936 & 22459.73 & 505563.4 & $2.07 \mathrm{E}+18$ \\
\hline 5 & 41492.25 & 481.694 & 3594.658 & 89838.93 & 4044507 & $2.07 \mathrm{E}+22$ \\
\hline 6 & 124476.8 & 802.8233 & 7908.248 & 359355.7 & 32356059 & $2.07 \mathrm{E}+26$ \\
\hline 7 & 373430.3 & 1338.039 & 17398.15 & 1437423 & $2.59 \mathrm{E}+08$ & $2.07 \mathrm{E}+30$ \\
\hline 8 & 1120291 & 2230.065 & 38275.92 & 5749692 & $2.07 \mathrm{E}+09$ & $2.07 \mathrm{E}+34$ \\
\hline 9 & 3360872 & 3716.774 & 84207.03 & 22998767 & $1.66 \mathrm{E}+10$ & $2.07 \mathrm{E}+38$ \\
\hline 10 & 10082617 & 6194.624 & 185255.5 & 91995068 & $1.33 \mathrm{E}+11$ & $2.07 \mathrm{E}+42$ \\
\hline
\end{tabular}

Table 24. The return period of the occurrence of n-days heat waves in Noshahr station

\begin{tabular}{ccccccc}
\hline n Days & \multicolumn{5}{c}{ Noshahr } \\
\cline { 2 - 7 } & Sep & Aug & July & June & May & April \\
\hline 1 & 7330001 & 196.7391 & 212.6288 & 930 & 9280001 & 8900001 \\
2 & $7.33 \mathrm{E}+10$ & 377.0832 & 602.4482 & 1860 & $9.28 \mathrm{E}+10$ & $8.9 \mathrm{E}+10$ \\
3 & $7.33 \mathrm{E}+14$ & 722.7428 & 1706.937 & 3720 & $9.28 \mathrm{E}+14$ & $8.9 \mathrm{E}+14$ \\
4 & $7.33 \mathrm{E}+18$ & 1385.257 & 4836.321 & 7440 & $9.28 \mathrm{E}+18$ & $8.9 \mathrm{E}+18$ \\
5 & $7.33 \mathrm{E}+22$ & 2655.076 & 13702.91 & 14880 & $9.28 \mathrm{E}+22$ & $8.9 \mathrm{E}+22$ \\
6 & $7.33 \mathrm{E}+26$ & 5088.896 & 38824.91 & 29760 & $9.28 \mathrm{E}+26$ & $8.9 \mathrm{E}+26$ \\
7 & $7.33 \mathrm{E}+30$ & 9753.716 & 110003.9 & 59520 & $9.28 \mathrm{E}+30$ & $8.9 \mathrm{E}+30$ \\
8 & $7.33 \mathrm{E}+34$ & 18694.62 & 311677.7 & 119040 & $9.28 \mathrm{E}+34$ & $8.9 \mathrm{E}+34$ \\
9 & $7.33 \mathrm{E}+38$ & 35831.36 & 883086.9 & 238080 & $9.28 \mathrm{E}+38$ & $8.9 \mathrm{E}+38$ \\
10 & $7.33 \mathrm{E}+42$ & 68676.78 & 2502079 & 476160 & $9.28 \mathrm{E}+42$ & $8.9 \mathrm{E}+42$ \\
\hline
\end{tabular}


Table 25. The return period of the occurrence of $n$-days heat waves in Gorgan station

\begin{tabular}{ccccccc}
\hline n days & \multicolumn{5}{c}{ Gorgan } \\
\cline { 2 - 6 } & Sep & August & July & June & May & April \\
\hline & 1568001 & 71.83393 & 78.74415 & 163.5892 & 814.3977 & - \\
\hline 1 & $1.57 \mathrm{E}+10$ & 197.5433 & 167.7593 & 838.3946 & 7329.58 & - \\
3 & $1.57 \mathrm{E}+14$ & 543.2441 & 357.4002 & 4296.773 & 65966.22 & - \\
4 & $1.57 \mathrm{E}+18$ & 1493.921 & 761.4178 & 22020.96 & 593695.9 & - \\
5 & $1.57 \mathrm{E}+22$ & 4108.283 & 1622.151 & 112857.4 & 5343263 & - \\
6 & $1.57 \mathrm{E}+26$ & 11297.78 & 3455.887 & 578394.3 & 48089371 & - \\
7 & $1.57 \mathrm{E}+30$ & 31068.89 & 7362.541 & 2964271 & $4.33 \mathrm{E}+08$ & - \\
8 & $1.57 \mathrm{E}+34$ & 85439.46 & 15685.41 & 15191887 & $3.9 \mathrm{E}+09$ & - \\
9 & $1.57 \mathrm{E}+38$ & 234958.5 & 33416.75 & 77858419 & $3.51 \mathrm{E}+10$ & - \\
10 & $1.57 \mathrm{E}+42$ & 646135.9 & 71192.21 & $3.99 \mathrm{E}+08$ & $3.16 \mathrm{E}+11$ & - \\
\hline
\end{tabular}

Table 26. The return period of the occurrence of n-days heat waves in Qazvin station

\begin{tabular}{ccccccc}
\hline \multirow{2}{*}{ n days } & \multicolumn{7}{c}{ Qazvin } \\
\cline { 2 - 7 } & Sep & August & July & June & May & April \\
\hline & - & 218.7064 & 76.40668 & 579.4833 & - & - \\
2 & - & 628.7809 & 181.9207 & 2028.192 & - & - \\
3 & - & 1807.745 & 433.1444 & 7098.671 & - & - \\
4 & - & 5197.267 & 1031.296 & 24845.35 & - & - \\
5 & - & 14942.14 & 2455.467 & 86958.72 & - & - \\
6 & - & 42958.66 & 5846.351 & 304355.5 & - & - \\
7 & - & 123506.2 & 13919.88 & 1065244 & - & - \\
8 & - & 355080.2 & 33142.58 & 3728355 & - & - \\
9 & - & 1020856 & 78910.9 & 13049243 & - & - \\
10 & - & 2934960 & 187883.1 & 45672349 & - & - \\
\hline
\end{tabular}

Table 27. The return period of the occurrence of $n$-days heat waves in Tehran station

\begin{tabular}{ccccccc}
\hline n days & \multicolumn{7}{c}{ Tehran } \\
\cline { 2 - 6 } & Sep & August & July & June & May & April \\
\hline 1 & - & 247.1667 & 52.9286 & 397.6 & - & - \\
2 & - & 617.9167 & 98.89292 & 795.2 & - & - \\
3 & - & 1544.792 & 184.7736 & 1590.4 & - & - \\
4 & - & 3861.979 & 345.2349 & 3180.8 & - & - \\
5 & - & 9654.948 & 645.0442 & 6361.6 & - & - \\
6 & - & 24137.37 & 1205.214 & 12723.2 & - & - \\
7 & - & 60343.42 & 2251.847 & 25446.4 & - & - \\
8 & - & 150858.6 & 4207.399 & 50892.8 & - & - \\
9 & - & 377146.4 & 7861.193 & 101785.6 & - & - \\
10 & - & 942866 & 14688.02 & 203571.2 & - & - \\
\hline
\end{tabular}


Table 28. The return period of the occurrence of n-days heat waves in Ramsar station

\begin{tabular}{|c|c|c|c|c|c|c|}
\hline \multirow[t]{3}{*}{ n days } & \multicolumn{6}{|c|}{ Ramsar } \\
\hline & \multicolumn{6}{|c|}{ month } \\
\hline & Sep & August & July & June & May & April \\
\hline 1 & 7840001 & 266.3231 & 192.5 & 994 & 9920001 & 4755001 \\
\hline 2 & $7.84 \mathrm{E}+10$ & 932.1308 & 577.5 & 1988 & $9.92 \mathrm{E}+10$ & $4.76 \mathrm{E}+10$ \\
\hline 3 & $7.84 \mathrm{E}+14$ & 3262.458 & 1732.5 & 3976 & $9.92 \mathrm{E}+14$ & $4.76 \mathrm{E}+14$ \\
\hline 4 & $7.84 \mathrm{E}+18$ & 11418.6 & 5197.5 & 7952 & $9.92 \mathrm{E}+18$ & $4.76 \mathrm{E}+18$ \\
\hline 5 & $7.84 \mathrm{E}+22$ & 39965.11 & 15592.5 & 15904 & $9.92 \mathrm{E}+22$ & $4.76 \mathrm{E}+22$ \\
\hline 6 & $7.84 \mathrm{E}+26$ & 139877.9 & 46777.5 & 31808 & $9.92 \mathrm{E}+26$ & $4.76 \mathrm{E}+26$ \\
\hline 7 & $7.84 \mathrm{E}+30$ & 489572.6 & 140332.5 & 63616 & $9.92 \mathrm{E}+30$ & $4.76 \mathrm{E}+30$ \\
\hline 8 & $7.84 \mathrm{E}+34$ & 1713504 & 420997.5 & 127232 & $9.92 \mathrm{E}+34$ & $4.76 \mathrm{E}+34$ \\
\hline 9 & $7.84 \mathrm{E}+38$ & 5997264 & 1262993 & 254464 & $9.92 \mathrm{E}+38$ & $4.76 \mathrm{E}+38$ \\
\hline 10 & $7.84 \mathrm{E}+42$ & 20990423 & 3788978 & 508928 & $9.92 \mathrm{E}+42$ & $4.76 \mathrm{E}+42$ \\
\hline
\end{tabular}

Table 29. The return period of the occurrence of $n$-days heat waves in Semnan station

\begin{tabular}{ccccccc}
\hline \multirow{2}{*}{ n days } & \multicolumn{7}{c}{ Semnan } \\
\cline { 2 - 6 } & \multicolumn{7}{c}{ month } \\
\hline & Sep & August & July & June & May & April \\
\hline 1 & 16.07215 & 111.6614 & 241.2595 & 99.54262 & 13.08104 & 34.52536 \\
2 & 17.66539 & 112.6975 & 242.2731 & 100.5817 & 15.28388 & 53.7497 \\
3 & 19.41656 & 113.7431 & 243.2911 & 101.6316 & 17.85767 & 83.67851 \\
4 & 21.34134 & 114.7985 & 244.3133 & 102.6925 & 20.86489 & 130.2722 \\
5 & 23.45691 & 115.8636 & 245.3399 & 103.7644 & 24.37852 & 202.8102 \\
6 & 25.78221 & 116.9386 & 246.3707 & 104.8476 & 28.48384 & 315.7386 \\
7 & 28.33801 & 118.0236 & 247.4059 & 105.942 & 33.2805 & 491.5475 \\
8 & 31.14717 & 119.1187 & 248.4454 & 107.0479 & 38.88491 & 765.2502 \\
9 & 34.2348 & 120.2239 & 249.4893 & 108.1653 & 45.43309 & 1191.355 \\
10 & 37.62851 & 121.3394 & 250.5376 & 109.2943 & 53.08399 & 1854.724 \\
\hline
\end{tabular}

Table 30. The return period of the occurrence of $n$-days heat waves in Shahrud station

\begin{tabular}{ccccccc}
\hline n days & \multicolumn{7}{c}{ Shahrud } \\
\cline { 2 - 6 } & Sep & August & July & June & May & April \\
\hline 1 & 925.1 & 52.03579 & 29.35249 & 49.81397 & - & - \\
2 & 10176.1 & 91.58299 & 41.53654 & 81.40331 & - & - \\
3 & 111937.1 & 161.1861 & 58.77812 & 133.0249 & - & - \\
4 & 1231308 & 283.6875 & 83.17659 & 217.3822 & - & - \\
5 & 13544389 & 499.2899 & 117.7027 & 355.2343 & - & - \\
6 & $1.49 \mathrm{E}+08$ & 878.7503 & 166.5604 & 580.5048 & - & - \\
7 & $1.64 \mathrm{E}+09$ & 1546.601 & 235.6987 & 948.6299 & - & - \\
8 & $1.8 \mathrm{E}+10$ & 2722.017 & 333.536 & 1550.2 & - & - \\
9 & $1.98 \mathrm{E}+11$ & 4790.75 & 471.9848 & 2533.254 & - & - \\
10 & $2.18 \mathrm{E}+12$ & 8431.72 & 667.9031 & 4139.707 & - & - \\
\hline
\end{tabular}




\subsection{Evaluating the Extracted from the Heat Wave Tables}

Regarding the heat wave index that was mentioned in table 2-3, the days whose maximum temperature was higher than the index were identified and categorized monthly according to each station. Then the days whose number of heat waves was between 3 to 6 days in each station, were recognized as the short term term wave and those days whose heat wave was more than 6 days were classified as long term term wave (Baldi, 2004:2). The findings from heat wave tables and also the diagrams 2-7 demonstrate that the most number of short term term heat waves in the northern hillside belong terms to Gorgan, which has happened 47 times in July and the most number of long term term heat waves belong terms to Qaem Shahr which has happened 9.1. While the most number of short term term heat wave in the southern hillside has happened 232 times in Semnan in May and the long term wave heat wave with the occurrence of 56.5 belong terms to the same city in the same month. No heat wave was observed in the southern hillside in May and April except in Ardabil and Semnan. While in the stations of the northern hillside, the heat wave is observed in all the stations except in Astara in April and May and in Gorgan in April. Regarding the short term term heat wave (47 occurrences in the northern hillside and 232 occurrences in the southern hillside) and also long term tern heat wave (9.1 occurrences in the northern hillside and 156.5 in the southern hillside), there is significant difference between the stations of the two hillsides. Generally speaking, the most number of short term term heat wave in all the months, among the northern hillside stations belong term to Gorgan with 115 days and the long term term heat wave belong terms to Qaem Shahr with 34.5 days of occurrence. In the southern hillside, both short term term and long term term belong term to Semnan with 550 and 438 days respectfully.

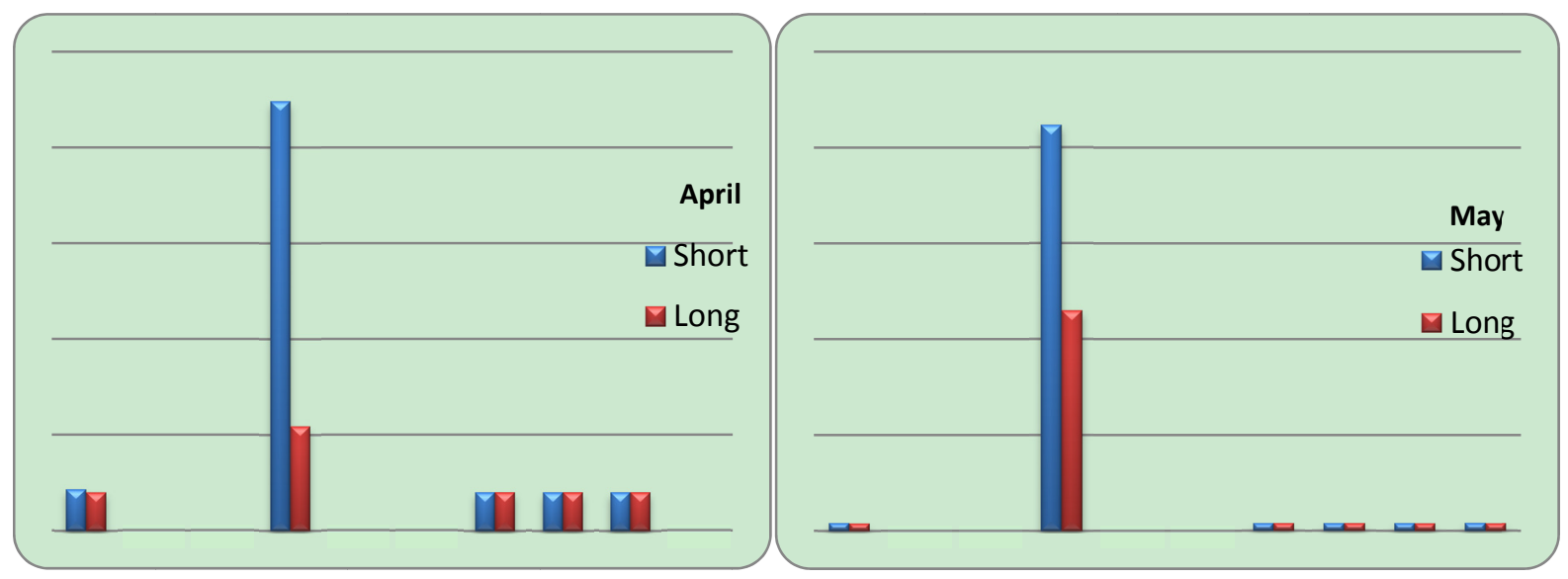

Figure 2, 3. The comparison of heat wave (short term -long term) in April \& May
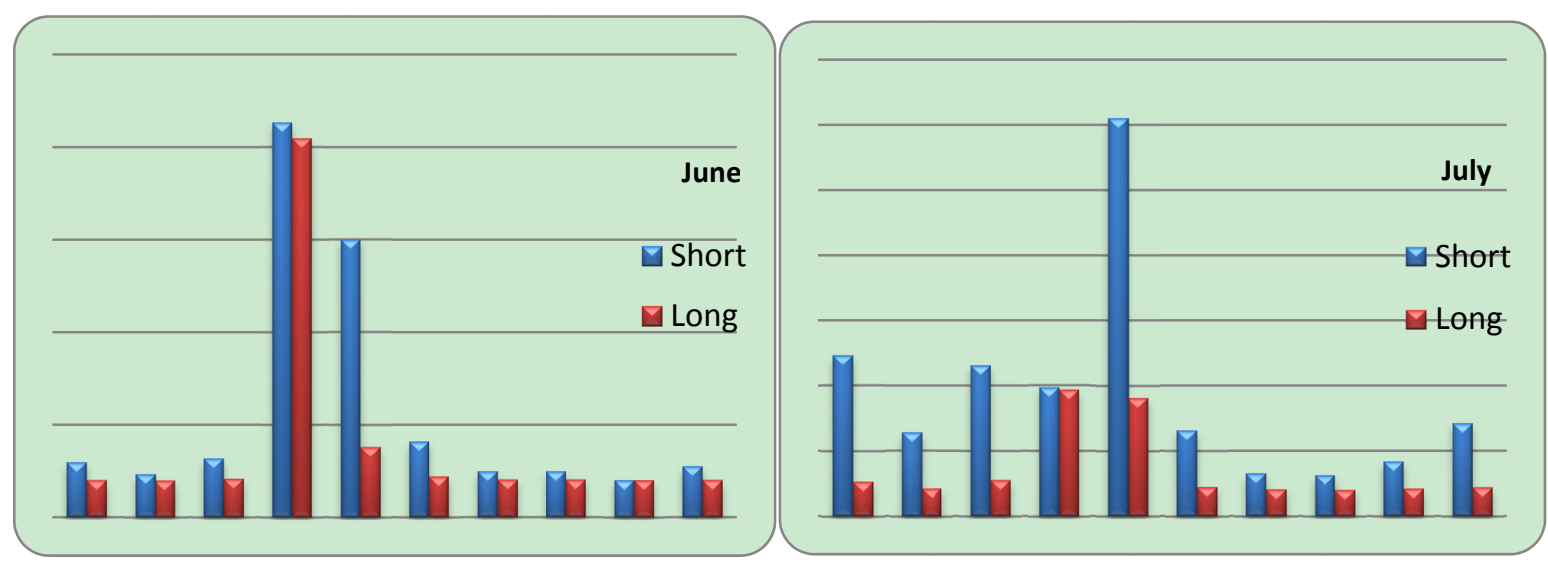

Figure 4, 5. The comparison of heat wave (short term -long term) in June \& July 

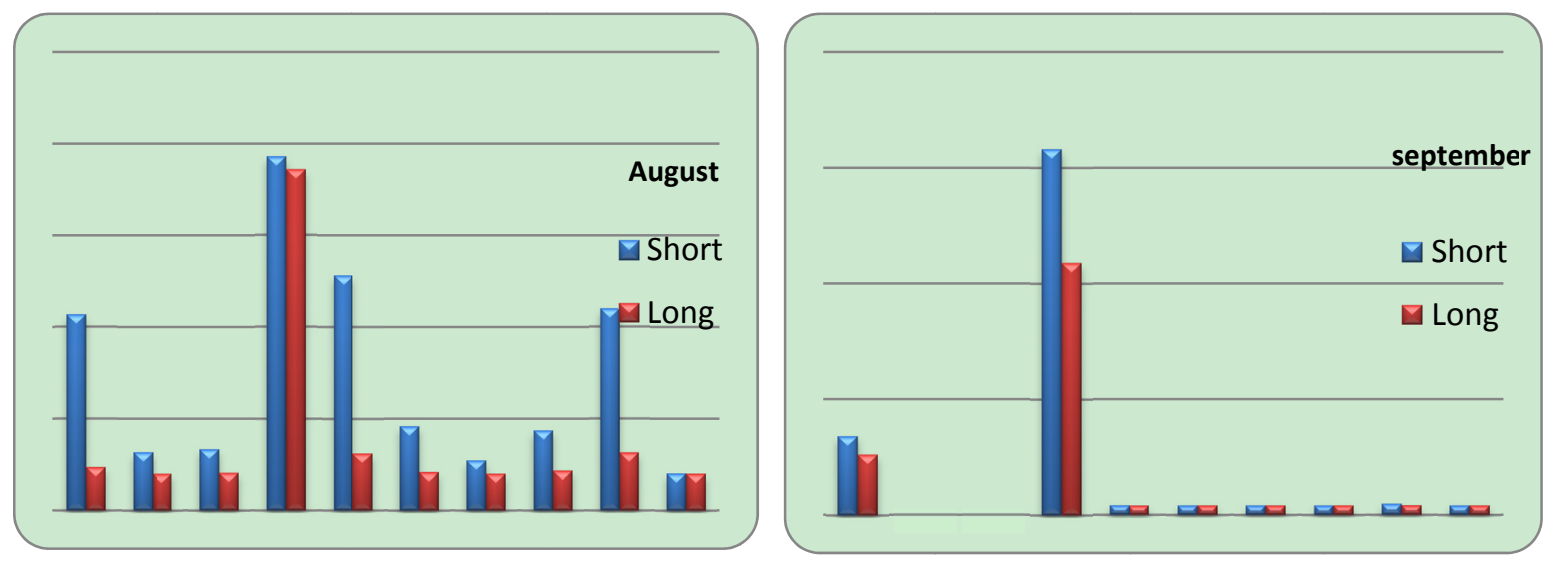

Figure 6, 7. The comparison of heat wave (short term -long term) in August \& September

Analyzing the features of persistence periods of heat wave, the conditions of selected stations were studied by using the Markov Chain Model. There is no heat wave in the stations of the northern hillside in April (P00). While in the southern hillside, the P00 is 95\% and 99.78\% for Semnan and Ardabil in April respectively. Besides, the highest frequency is for a heat wave which occur exactly after another wave which in the southern hillside is for Ardabil, Shahrud, Tehran, Qazvin and the highest one belong terms to Semnan (51\%, 71\%,54\% 42\%,100\% respectively). In the northern hillside, Ramsar, Noshahr and Astara (50\%,50\% 55\%) in June and Gorgan and Qaem Shahr $(47 \%, 46 \%)$ in July have the probability of P11. The probability of one day without heat wave, after which happens a day with heat wave, varies in the northern hill between $2 \%$ in Ramsar and $4 \%$ in Gorgan and it has happened in July more than any time else, but in the southern hillside it varies in all the stations between 4 to $5 \%$ except for Semnan which has the probability of $80 \%$.

\subsection{Analyzing the Forecasting Periods of $n$ days Persistence}

In this step, the persistence periods of the heat waves that lasted between 1 to 10 days from April to September were computed and the results were shown in the tables 12 to 21 . The short term hot periods (mainly 3 to 6 days) have the highest frequency in all the stations and seasons which were studied and the frequency of long termer periods decreases gradually i.e. the number of the heat waves which were 5 to 10 days decreases in almost all the stations and in all the months and this decrease is more obvious in the northern stations and Semnan shows a different situation among the southern hillside stations. According to the Tables $11-13$, it is obvious that the frequency of the hot days which lasted 5 to 10 days in the southern hillside stations is more than northern hillside stations which shows the persistence of hot days in this region. The highest frequencies are observed in June, July and then in August. The maximum number of one- day heat wave in the northern hillside stations are 22 days in Astara in July, 21 days in Qaem Shahr in August, 13 days in Noshahr in July, 32 days in Gorgan in June and 16 days in Ramsar in July. This numbers for the southern hillside stations are 31 days for Qazvin, 35 days in Tehran and 46 days in Shahrud in July, 90 days in Semnan in May and 50 days in Ardabil in August. The frequency of ten-day heat wave in all the northern hillside stations is small but among the southern hillside stations, Semnan and Shahrud are more than other cities. The most number of ten-day heat wave in Semnan lasts 24 days and happens in September which shows a noticeable temperature difference compared with other stations. There are no 1-10 day periods in the stations of Tehran, Shahrud, Qazvin and Astara in April and May.

\subsection{Analyzing the $n$-days Return Periods}

As it can be inferred from the tables, the return periods in all the stations and in all the seasons has increased numerically, but the frequency of the periods (one to ten days) has decreased (Tables). The return periods which lasted one to five days are less than the return periods which lasted 5-10 days in all the stations and in all the seasons. The least number of the return days has happened in June and July (1-3 days) and the most number has been observed in April and September in both the northern and southern hillsides. The 10-day return period in Semnan differs greatly from other stations. For example, the return period in May is 53 days and in September is 37 days, While, the return period in Tehran is 203571 days in June and 942866 days in August.

\section{Conclusion}

The existence of high mountains and various topographies has caused the spatial distribution of weather 
temperature not to follow a regular pattern. The increase of effectiveness of heat waves from the mountains and the height along term with the latitude is specified and also the effect of humidity on the temperature in the northern hillside and the lack of cloudiness in the southern hillside in the indication of heat waves are observed. The Markov Chain Model is efficiently used in order to estimate and recognize the heat waves in these two hillsides.

The results found by the Markov Chain Model in this research are represented below:

The increase trend of temperature in all the stations starts from April, reaches to the maximum amount in July and intends to decrease in September. The highest occurrence probability of heat wave is seen in Semnan, then in Shahrud and the least occurrence probability is observed in Noshahr and Ramsar in the selected years. The frequency of hot periods which lasted 1-5 days and specially 1-3 days are more than 5-10 days in all the stations in both the southern and northern hillside in all the months and the uniform distribution in the long term term waves can be observed in all the stations except Semnan and Shahrud. The highest happened heat waves whether they are long term term or short term term have occurred in June and July in both hillsides and the least amount has happened in April. Semnan has the highest heat wave among the selected stations. The difference between the occurrence frequencies in the return period is noticeable. Comparing the short term term (47 occurrences in the northern hillside and 232 in the southern hillside) and long term term (9.1 in the northern hillside and 156.5 in the southern hillside) heat waves of the southern and northern hillsides, the significant difference between the stations of both hillsides can be observed. The below results has been achieved by comparing the corresponding stations: the researcher has compared Qazvin with its corresponded station which is Ramsar and has found that the mean temperature of Qazvin varies between 20 to 35 degrees in the selected months and in Ramsar, it varies between 16 to 28 degrees. No heat wave has been seen in Qazvin in September, April and May and the highest number of one-day heat wave has happened 31 times in July while the heat wave has happened in all the months in Ramsar. There is no difference between the frequencies of 5-10 day heat wave. Comparing the Gorgan and Shahrud, it can be shown that the mean temperature of Gorgan varies between 21 to 33 degrees and in Shahrud varies between 18 to 30 degrees. The highest number of short term term waves in Gorgan is 47 days; in Shahrud is 101.7 days and the long term term heat waves are 6 and 27 days respectively which show significant difference. The results found by the comparison of Ardabil and Astara indicate that highest frequency of one-day heat wave in Ardabil is 50 days in August and is 22 days in Astara. There is no heat wave in April and May in Astara but it can nearly be observed in Ardabil. The comparison of Noshahr with Tehran represent that the number of long term term heat waves in Tehran is 8 and in Noshahr is 5.7 in July while the short term term heat wave in Tehran and Noshahr are 64.7 and 20.7 respectively. The long termest return periods in Noshahr has happened in April, May and September, the occurrence frequency in all the months is not the same in Tehran. The short termest return period lasted one day is $\mathbf{5 2}$ days in July and 196 days in Noshahr in August. The remarkable results have been found when the researcher has compared Semnan and Qaem Shahr. The frequency of the heat wave has happened 24 times in Qaem Shahr in August and the heat wave has lasted one day and the 6-10 day periods have decreases but the prediction frequency reaches to 10 days and can be seen in all the months. The highest number of short term waves in Semnan is 232 days in May and the highest number for the long term wave is 156.5 in the same month while, they are 48 and 9 for Qaem Shahr respectively. The ten-day return period in Semnan is 37 in September and 109 in June.

Studying the heat waves in the hot months of the year, the research results demonstrate that the hot winds, forest firing and destruction of forests, disease outbreak, damage to animals, damage to agricultural products, the short termage of water resources and the need for the energy, the use of air conditioners and the change of tourists' destinations in a region increases and some strategies and plans should be suggested to prevent great losses.

\section{References}

Akan, A. O., \& Houghtalen, R. J. (2003). Urban Hydrology, Hydraulics, and Storm Water Quality. John Wily \&Sons. Inc, U.S.A.

Alijani, B. et al. (2011). Evaluation of the Structure of Continuance of the Two Situations of Raining in South Iran by Means of Markov Hidden Status Model. Geography and Development Journal, 25, 1-20.

Alijani, B., Jafarpour, Z., \& Ghaderi, H. (2005). Evaluation and Prediction of Raining in Larestan District by Means of Markov Chain Model. Sarzamin Geographical Journal, 7, 11-34.

Alizadeh, A. (2006). Applied Hydrology. Mashhad: Ferdowsi Publications.

Alizadeh, A., Javanmard, S., \& Ashgar Tousi, S. (2003). Analysis and Prediction of Famine in Khorasan Province. Geographical Research Journal, 128, 18-119. 
Anagnostopoulou, C., Maheras, P., Karacostas, T., \& Vafiadis, M. (2003). Spatial and temporal analysis of dry spells in Greece. Theor. Appl. Climates., (74), 77-91. http://dx.doi.org/10.1007/s00704-002-0713-5

Asakereh, H. (2008). Evaluation of the Probability of Frequency and Continuance of Rainy Days in Tabriz by Means of Markov Chain Model. Iranian Water Resources Research Journal, 2.

Asakereh, H. (2011). Principles of Statistical Climatology. Zanjan University Publications.

Asakereh, H., \& Mazini, F. (2010). Evaluation of the Probability of Occurrence of Dry Days in Golestan Province by Means of Markov Chain Model. Geography and Development Journal, 17, 17-44.

Ashgar Tousi, S., Alizadeh, A., \& Javanmard, S. (2001). Predicting the Occurrence of Famine in Khorasan Province. Geographical Research Journal, (528), 120.

Baldi, M. et al. (2004). Heat Wave in The Mediterranean Region Analysis and Model Results, institute of biometeorology -CNR.ROM.ITALY No, 10.

Barron J., Rockstrom, J., Gichuki, F., \& Hatibu, N. (2003). Dry Spell Analysis and Maize Yields for Two Semiarid Locations in east Africa. Agricultural and Forest Meteorology, 117, 23-37. http://dx.doi.org/10.1016/S0168-1923(03)00037-6

Berger, A., \& Goossens, C. H. R. (1983). Persistence of wet and dry spells at Uccle (Belgium). J. Climatol, 3, 21-34. http://dx.doi.org/10.1002/joc.3370030103

Colacino, M. (1995). Heat wave in the Central Mediterranean a Synoptic Climatology instituted di fisica dell' Atmospheric fear (CNR) Roma. Italy.

Diaz, J., Cristina, L., \& Aurelio, T. (2006). A Critical comment on heat Wave response plans. European Journal of publication health, 16(6), 600. http://dx.doi.org/10.1093/eurpub/ckl228

Ghamghami, M., \& Bazrafshan, J. (2012). Augury of Famine Situation Allover Iran by Means of Markov Chain Model. Water and Soil Protection Journal, 3.

Grigorten, I. L. (1966). A Stochastic Model of the Frequency and Duration of Weather Events. Journal of Applied Meteorology, 5, 606. http://dx.doi.org/10.1175/1520-0450(1966)005<0606:ASMOTF>2.0.CO;2

Hanson, C. L., Neff, E. L., \& Woolhiser, D. A. (1975). Hydrologic aspects of water harvesting in the Northern Great Plains. p: 129-140. Proceedings of Water Harvesting Symposium, ARS W-22, U. S. Department of Agriculture Agric, Res. Service. Water Conservation La.

Hashemi, F. (1968). Statistical Analysis of the Annual, Monthly and Daily Raining in Tehran. Iranian Scientific Research in Meteorology. Tehran

Hoseini, F. et al. (2012). Evaluation of Time and Location Changes in Famine and Season Periods in Khorasan Province. Water and Soil Journal, 28, 2.

Jafari Behi, K. (1999). Statistical Analysis of Wet and Dry Periods of Raining in Some Continental Samples of Iran by Means of Markov Chain Model. M.A. Thesis of Agricultural Meteorology. Agriculture Faculty of Tehran University.

Jalali, M., Kargar, H., \& Soltani, S. (2011). Evaluation of the Probability of Occurrence of Rainy Days in Oroumieh by Means of Markov Chain Model. Ahar Geographical Space Journal, 35, 235-257.

Kamali, G., \& Khazanehfari, L. (2002). Analysis of the Recent Famine in Mashhad by utilization of some Famine Indices. Nivar Journal, 44.

Martin Vide, J., \& Gomez, L. (1998). Regionalization of peninsular Spain based on the length of dry spells. $\begin{array}{lllll}\text { International of Journal } & \text { climatology, } & 19, & 537-555 .\end{array}$ http://dx.doi.org/10.1002/(SICI)1097-0088(199904)19:5<537::AID-JOC371>3.0.CO;2-X

Masoudian, S. A. (2011). Iran's Climate. Mashhad: Sharieh Toos

Mehrotra, R., \& Sharma, A. (2007). A stochastic daily rainfall occurrence generator with higher time scale dependence. Geophysical Research Abstracts.

Meshkani, M. (1974). Evaluation of the Probability of Frequency of Dry Days in Babolsar from Experimental Point of View. Water Sciences Journal, 3.

Saligheh, M. et al. (2011). Spatial analysis of Raining in Wet Seasons of the Year by Means of Markov Chain Model, Case Study: Ardebil Province. Applied Research in Geographical Sciences, 20.

Seleshi, Y., \& Camberlin, P. (2006). Recent changes in dry spell and extreme rainfall events in Ethiopia. Theor. 
Appl. Climatic., 83, 181-191. http://dx.doi.org/10.1007/s00704-005-0134-3

Shirkhani, A., \& Hejazi Zadeh, Z. (2005). Analysis and Statistical Prediction of Famine and Short term-Term Dry Periods in Khorasan Province. Geographical Researches, 52.

Taleshi, A. (2005). Modeling of Annual Raining in Iran by Means of Markov Chain Model. M.A. Thesis, Tabriz University

Yazdan Panad, H., \& Alizadeh, T. (2011). Estimation of the Probability of Occurrence of Thermal Waves with Different Duration Periods in Kerman Province by Means of Markov Model. Geographical Research Journal, (3).

Yousefi, N., \& Hejam, S. (2007, Summer). Estimation of the Probability of Dry and Wet Years by Means of Markov Chain Model and Normal Distribution, Case Study: Qazvin. Geographical Research, 3.

\section{Copyrights}

Copyright for this article is retained by the author(s), with first publication rights granted to the journal.

This is an open-access article distributed under the terms and conditions of the Creative Commons Attribution license (http://creativecommons.org/licenses/by/3.0/). 